\title{
PENGARUH LEVERAGE DAN PERPUTARAN MODAL KERJA TERHADAP PROFITABILITAS PERUSAHAAN SUB SEKTOR OTOMOTIF DAN KOMPONEN YANG TERDAFTAR DI BURSA EFEK INDONESIA TAHUN 2011-2015
}

\author{
Angelita ${ }^{1)}$, \& Humisar Sihombing ${ }^{2)^{*}}$ \\ 1) Fakultas Ekonomi, Universitas Negeri Medan \\ 2) Fakultas Ekonomi, Universitas Negeri Medan \\ E-mail : humisarsihombing30@gmail.com
}

\begin{abstract}
Abstrak
Penelitian ini dilakukan untuk menjelaskan beberapa faktor yang diduga berpengaruh terhadap profitabilitas diantaranya pemanfaatan leverage dan perputaran modal kerja. Populasi penelitian sebanyak 13 perusahaan dan sampel yang diteliti sebanyak 12 perusahaan. Teknik analisis yang digunakan dalam penelitian ini adalah deskriptif kuantitatif menggunakan analisis jalur dengan hasil persamaan $\mathrm{X}_{2}=0,335 \mathrm{X}_{1}+0,938, \mathrm{X}_{3}$ $=-0,440 \mathrm{X}_{1}+0,038 \mathrm{X}_{2}+0,900$. Uji hipotesis menunjukkan hasil koefisien jalur leverage terhadap perputaran modal kerja sebesar 0,335 pada taraf signifikan 0,009 , leverage terhadap profitabilitas sebesar $-0,440$ pada taraf signifikansi 0,001 dan perputaran modal kerja terhadap profitabilitas sebesar 0,038 pada taraf signifikan 0,764 . Hasil penelitian menunjukkan bahwa terdapat pengaruh leverage terhadap perputaran modal kerja, terdapat pengaruh leverage terhadap profitabilitas, terdapat pengaruh perputaran modal kerja terhadap profitabilitas.
\end{abstract}

\section{Kata kunci : Leverage, Perputaran Modal Kerja, Profitabilitas.}

\begin{abstract}
This research is conducted to explain some factors that allegedly have an effect on to profitability such as utilization of leverage and working capital turnover. Population used in this research is 13 companies and the sample that use in this research is 12 companies. The analysis technique used in this research is descriptive quantitative by using path analysis with the result of equation $X_{2}=0,335 X_{1}+0,938, X_{3}=-0,440 X_{1}+0,038 X_{2}+$ 0,900 . Hypothesis test shows the result of coefficient of leverage path to working capital turnover is 0,335 at significant level 0,009, leverage to profitability is $-0,440$ at significance level 0,001 and work capital turnover to profitability is 0,038 at significant level 0,764. The result of research indicate that there is influenced of leverage to working capital turnover, there is influenced of leverage to profitability, there influenced of working capital turnover to profitability.
\end{abstract}

Keywords: Leverage, Working Capital Turnover, and Profitability

\section{PENDAHULUAN}

Perusahaan otomotif dan komponen merupakan salah satu perusahaan sub sektor di Bursa Efek Indonesia yang semakin bertumbuh dan berkembang di Indonesia. Hal ini terlihat dari banyaknya produkproduk otomotif yang digunakan baik dari jenis maupun jumlahnya. Disamping perkembangan produknya, permintaan produk otomotif dimasyarakat juga meningkat 
diimbangi dengan pertumbuhan jumlah penduduk.

\section{Melihat}

fenomena

perkembangan produksi otomotif dan komponen maka hal ini berpengaruh pada keberhasilan perusahaan dalam mencapai tujuannya yang dapat dilihat dari profitabilitasnya. Profitabilitas adalah kemampuan perusahaan untuk menghasilkan laba pada periode tertentu melalui semua kemampuan dan sumber yang ada (Harahap 2008:302). Namun pada kenyataannya profitabilitas perusahaan sub sector otomotif dan komponen tidak sejalan dengan tingginya penjualan maupun permintaan yang ada di pasar. Dimana ketika penjualan produk otomotif dan komponen meningkat tidak ikuti dengan kenaikan profitabilitas perusahaan otomotif dan komponen.

Profitabilitas perusahaan otomotif dan komponen terus menurun. Hal ini memberikan arti bahwa perusahaan belum mampu mewujudkan tujuannya. Jika ini terus menerus terjadi akan menimbulkan masalah, khususnya bagi investor. Dimana investor akan menarik dana atau investasinya sehingga perusahaan akan kesulitan mendapatkan dana untuk kegiatan produksinya. Oleh karena itu perlu dilakukan penelitian atau pengkajian untuk mengetahui apa penyebab penurunan profitabilitas yang pada akhirnya dapat dicari solusinya.

Salah satu faktor yang mempengaruhi profitabilitas adalah leverage. Leverage merupakan penggunaan dana yang akan menimbulkan beban bunga yang harus dibayar perusahaan (Irawati, 2006 : 122). Leverage memiliki perang yang penting dalam sebuah perusahaan. leverage perusahaan berfluktuasi namun terjadi kenaikan leverage di tahun 2015. Leverage yang semakin tinggi berarti beban bunga perusahaan juga semakin tinggi dan berpengaruh pada laba yang diperoleh lebih kecil. Namun, ketika leverage digunakan secara efektif maka dapat menaikkan profitabilitas, sehingga laba yang di hasilkan lebih besar dari beban bunga yang dibayar.

Disamping faktor leverage dapat mempengaruhi profitabilitas, faktor lain adalah perputaran modal kerja. Perputaran modal kerja menunjukkan kefektifan pendayagunaan modal kerja untuk melakukan kegiatan perusahaan (Yudiana, 2013:103). Maka penting bagi perusahaan untuk terus meningkatkan perputaran modal kerja yang dimiliki. Pada perusahan otomotif dan komponen jumlah perputaran modal kerja cenderung menurun. Ketika perputaran modal kerja menurun hal ini berarti kemampuan perusahaan juga menurun dalam menghasilkan laba dari penggunaan modal kerja yang dimiliki dan menunjukkan perusahaan tidak efektif dalam mengelola modal kerja yang dimiliki.

\section{METODE PENELITIAN}

Data yang digunakan dalam penelitian ini adalah data sekunder berupa laporan keuangan tahunan dan ringkasan kinerja keuangan perusahaan perusahaan sub sektor otomotif dan komponen yang diperoleh dengan mengunduh data dari situs resmi Bursa Efek Indonesia (http://www.idx.co.id). Populasi dalam penelitian ini adalah seluruh perusahaan sub sektor otomotif dan komponen yang terdaftar di Bursa Efek Indonesia periode 2011-2015, 
yaitu sebanyak 13 perusahaan. Metode pengambilan sampel adalah dengan purposive sampling, yaitu pemilihan berdasarkan kriteria. Berdasarkan analisis pemilihan sampel dengan kriteria diatas, ada 12 perusahaan yang memenuhi kriteria, maka ada 60 (12 x 5 tahun) data amatan yang digunakan dalam penelitian ini. Statistik deskriptif merupakan teknik statistik yang berfungsi mendeskripsikan atau memberikan gambaran terhadap objek yang diteliti melalui data sampel tanpa membuat kesimpulan yang berlaku secara umum dari data tersebut. Metode analisis yang digunakan dalam penelitian ini adalah dengan model analisis jalur (path analysis), yang berfungsi untuk menjelaskan mekanisme hubungan kausal antara variabel eksogen denagn variabel endogen.

\section{HASIL DAN PEMBAHASAN}

\section{Hasil Penelitian}

Analisis Jalur (Path Analysis)

\section{Uji Linieritas}

Dalam analisis jalur hubungan antar variabel harus linier. Berikut rangkuman hasil uji linieritas variabel penelitian :

Tabel 1.

Rangkuman Hasil Uji Linieritas

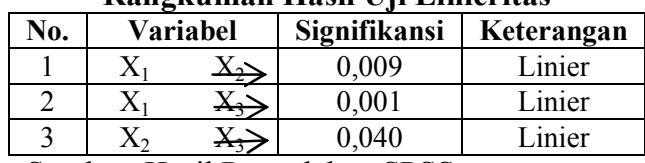

Sumber: Hasil Pengolahan SPSS

Dari tabel 1. dapat diketahui bahwa nilai signifikansi yang diperoleh dari seluruh variabel penelitian lebih kecil dari 0,05. Hasil ini menunjukkan bahwa semua hubungan antar variabel dalam penelitian ini bersifat linier.

\section{Uji Hipotesis}

Analisis jalur digunakan untuk menganalisis hubungan kausal antar variabel, di mana variabel-variabel bebas memengaruhi variabel-variabel terikat, baik secara langsung maupun secara tidak langsung melalui satu atau lebih variabel perantara.

Tabel 2.

\section{Uji Hipotesis}

\begin{tabular}{|c|c|c|c|c|}
\hline Variabel & $\begin{array}{c}\text { Koefisien } \\
\text { Jalur }\end{array}$ & $\mathrm{T}_{\text {hitung }}$ & $\mathrm{T}_{\text {tabel }}$ & Signifikansi \\
\hline $\begin{array}{c}\mathrm{X}_{1} \\
\mathrm{X}_{2}\end{array}$ & 0,335 & 2,709 & 2,001 & 0,009 \\
\hline $\begin{array}{c}\mathrm{X}_{1} \\
\mathrm{X}_{3}\end{array}$ & $\begin{array}{c}- \\
0,440\end{array}$ & 3,460 & 2,001 & 0,001 \\
\hline $\begin{array}{c}\mathrm{X}_{2} \\
\mathrm{X}_{3}\end{array}$ & 0,038 & 3,302 & 2,001 & 0,764 \\
\hline
\end{tabular}

Sumber: Hasil Pengolahan SPSS

Kerangka hubungan antar jalur dapat dilihat melalui persamaan sub-struktural sebagai berikut :

$$
\begin{aligned}
& X_{2}=0,335 X_{1}+0,938 \\
& X_{3}=-0,440 X_{1}+0,038 \\
& X_{2}+0,900
\end{aligned}
$$

Berdasarkan persamaan substruktural di atas dapat dilihat ada pengaruh langsung dan tidak langsung dari masing-masing variabel. Untuk lebih jelasnya dapat dilihat pada tabel berikut. :

Tabel 3. Pengaruh Langsung, Tidak Langsung dan Total

\begin{tabular}{|c|c|c|c|}
\hline Variabel & Langsung & $\begin{array}{c}\text { Tidak } \\
\text { Langsung }\end{array}$ & Total \\
\hline $\mathrm{X}_{1} \mathrm{X}_{2}$ & 0,335 & & 0,335 \\
\hline $\mathrm{X}_{1} \mathrm{X}_{3}$ & $-0,440$ & $\begin{array}{c}0,010 \\
\left(\text { Melalui } \mathrm{X}_{2}\right)\end{array}$ & $-0,430$ \\
\hline $\mathrm{X}_{2} \mathrm{X}_{3}$ & 0,038 & & 0,729 \\
\hline
\end{tabular}

Sumber: Hasil Pengolahan SPSS

\section{Pembahasan}

\section{Pengaruh Leverage terhadap Perputaran Modal Kerja}

Berdasarkan hasil penelitian, didapat nilai koefisien jalur variabel $\mathrm{X}_{1}$ terhadap $\mathrm{X}_{2}$ adalah $0,335\left(\mathbf{p} \mathbf{X}_{\mathbf{2}} \mathbf{X}_{\mathbf{1}}\right)$. Koefisien jalur tersebut memberikan arti bahwa $\mathrm{X}_{1}$ mempengaruhi $\mathrm{X}_{2}$ sebesar 33,5\% dengan arah positif. Dimana ketika nilai leverage semakin tinggi, maka nilai perputaran modal 
kerja akan ikut bergerak naik. Ada pengaruh leverage terhadap perputaran modal kerja hal ini dapat dilihat dari nilai $t_{\text {hitung }}$ sebesar 2,709 dan nilai $t_{\text {tabel }}$ dengan taraf signifikan 0,05 dan derajat kebebasan $(\mathrm{dk})=\mathrm{n}$ 2 , maka dk $=60-2=58$ sebesar 2,001 dengan demikian, nilai $t_{\text {hitung }}>t_{\text {tabel }}$ dan Sig. 0,009 $<0,05$ (signifikan). Hasil Penelitian mengindikasikan bahwa leverage berpengaruh positif dan signifikan terhadap perputaran modal kerja. Maka dari itu hipotesis yang dimunculkan oleh penulis yang menyatakan terdapat pengaruh leverage terhadap Perputaran Modal Kerja diterima. Hasil penelitian ini sesuai teori yang dikemukakan oleh Sawir (2005:141) yang menyatakan bahwa tambahan hutang merupakan salah satu sumber modal kerja yang akan mempercepat perputaran modal kerja pada suatu perusahaan

\section{Pengaruh Leverage terhadap Profitabilitas}

Berdasarkan hasil penelitian, didapat nilai koefisien jalur variabel $\mathrm{X}_{1}$ terhadap $\mathrm{X}_{3}$ adalah $-0,440$ $\left(\mathbf{p} \mathbf{X}_{3} \mathbf{X}_{1}\right)$. Koefisien jalur tersebut memberikan arti bahwa $\mathrm{X}_{1}$ mempengaruhi $\mathrm{X}_{3}$ sebesar $44 \%$ dengan arah negatif. Dimana ketika nilai leverage semakin tinggi, maka nilai profitabilitas akan bergerak turun. Ada pengaruh leverage terhadap profitabilitas hal ini dapat terlihat dari nilai $t_{\text {hitung }}$ sebesar 3,460 dan nilai $t_{\text {tabel }}$ dengan tarafsignifikan 0,05 dan derajat kebebasan $(\mathrm{dk})=\mathrm{n}$ 2 , maka dk $=60-2=58$ sebesar 2,001 dengan demikian, nilai $t_{\text {hitung }}>t_{\text {tabel }}$ dan Sig. 0,001 $<0,05$ (signifikan). Hasil penelitian mengindikasikan bahwa leverage berpengaruh negatif dan signifikan terhadap profitabilitas. Maka dari itu hipotesis yang dimunculkan oleh penulis yang menyatakan terdapat pengaruh leverage terhadap profitabilitas diterima. Penelitian ini didukung dengan penelitian yang telah dilakukan sebelumnya oleh Annas (2015) yang mengatakan bahwa semakin tinggi nilai leverage maka profitabilitasnya akan semakin menurun.

\section{Pengaruh Perputaran Modal Kerja terhadap Profitabilitas}

Berdasarkan hasil penelitian, didapat nilai koefisien jalur variabel $\mathrm{X}_{2}$ terhadap $\mathrm{X}_{3}$ adalah $0,038\left(\mathbf{p} \mathbf{X}_{\mathbf{3}} \mathbf{X}_{\mathbf{2}}\right)$. Koefisien jalur tersebut memberikan arti bahwa $\mathrm{X}_{2}$ mempengaruhi $\mathrm{X}_{3}$ sebesar 3,8\% dengan arah positif. Dimana ketika nilai perputaran modal kerja semakin tinggi, maka nilai profitabilitas akan ikut bergerak naik. Ada pengaruh perputaran modal kerja terhadap profitabilitas dengan nilai $t_{\text {hitung }}$ sebesar 3,302 dan nilai $t_{\text {tabel }}$ dengan taraf signifikan 0,05 dan derajat kebebasan $(\mathrm{dk})=\mathrm{n}-2$, maka $\mathrm{dk}=60-2=58$ sebesar 2,001 dengan demikian, nilai $t_{\text {hitung }}>t_{\text {tabel }}$ dan Sig. $0,764>0,05$ (tidak signifikan).

Hasil penelitian ini mengindikasikan bahwa perputaran modal kerja berpengaruh positif tidak signifikan terhadap profitabilitas, maka dari itu hipotesis yang dimunculkan oleh penulis yang menyatakan terdapat pengaruh perputaran modal kerja terhadap profitabilitas diterima namun pengaruhnya tidak signifikan. Penelitian ini memperkuat penelitian yang telah dilakukan sebelumnya oleh Agustina (2014) yang mengatakan bahwa penggunaan modal kerja secara efektif dan efisien hanya berpengaruh kecil atau sedikit terhadap kenaikan profitabilitas. 
JURNAL PLANS

Penelitian Ilmu Manajemen \& Bisnis

ISSN: 1978-7057

E-ISSN: 2527-306X

\section{SIMPULAN}

Leverage secara parsial berpengaruh positif dan signifikan terhadap perputaran modal kerja pada perusahaan Otomotif dan Komponen yang terdaftar di Bursa efek Indonesia. Leverage secara parsial berpengaruh negatif dan signifikan terhadap profitabilitas pada perusahaan Otomotif dan Komponen yang terdaftar di Bursa efek Indonesia. Perputaran modal kerja secara parsial berpengaruh positif namun tidak signifikan terhadap profitabilitas pada perusahaan Otomotif dan Komponen yang terdaftar di Bursa efek Indonesia.

DAFTAR PUSTAKA

Agustina, Yuyun. 2014. Pengaruh Pembiayaan Jual Beli, Pembiayaan Bagi Hasil dan Rasio Non Performing Financing (NPF) terhadap Profitabilitas (ROA) Bank Umum Syariah di Indonesia Periode 2008-2012. Skripsi.
Universitas Muhammadiyah Surakart

Annas, Dafid Syaiful. 2015. Pengaruh Profitabilitas, Likuiditas, dan Leverage terhadap peringkat obligasi dengan Manajemen Laba sebagai Variabel Intervening pada Perusahaan Non Keuangan. Skripsi. Universitas Negeri Semarang

Harahap, Sofyan. 2008. Analisis Kritis Atas Laporan Keuangan. Jakarta: PT. Raja Grafindo

http://www.idx.co.id di akses tanggal 27 Januari 2017

Irawati, Susan. 2006. Manajemen Keuangan. Bandung:Pustaka

Sawir, Agnes. 2001. Analisis Kinerja Keuangan dan Perencanaan Keuangan Perusahaan. Jakarta: PT Gramedia Pustaka Utama. Sjahrial, Dermawan. 2009. Pengantar Manajemen Keuangan. Jakarta:Mitra Wacana Media 